\title{
Growth and Yield Performance of Summer Sesamum Based Intercropping Systems
}

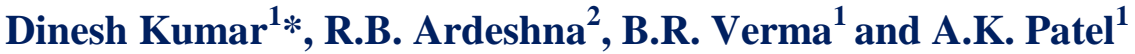 \\ ${ }^{1}$ Department of Agronomy, ${ }^{2}$ N. M. College of Agriculture, Navsari Agricultural University, \\ Navsari - 396 450, Gujarat, India \\ *Corresponding author
}

\section{A B S T R A C T}

\section{Keywords \\ Seed, stalk, dry matter per plant, harvest index, intercrops, green gram, cowpea.}

\section{Article Info}

\section{Accepted:}

20 May 2017

Available Online:

10 June 2017
A field experiment was conducted at College Farm, Navsari Agricultural University, Navsari (Gujarat) to study the production potential of summer sesamum based intercropping systems during summer season of 2016. The experiment was carried out in randomized block design with four replications and nine treatments. Plant stand per metre row length as well as days to 50 per cent flowering of sesamum was not influenced significantly by various treatments. Plant height of sesamum was maximum in sesamum + green gram (Paired 3:2) (68.64 and $102.59 \mathrm{~cm}$ at 45 DAS and harvest, respectively), whereas number of branches per plant and dry matter accumulation were remarkably higher in sole sesamum as compared to intercropping treatments. Among intercropping treatments, sesamum + green gram (Paired 3:2) recorded maximum number of branches per plant (2.65 and 3.55 at 45 DAS and harvest, respectively) and dry matter accumulation (5.45 and $10.53 \mathrm{~g} / \mathrm{plant}$ at45 DAS and harvest, respectively). Sole sesamum (Normal and paired rows sowing) recorded higher number of capsule per plant, capsule length, number of seeds per capsule and test weight as compared to intercropping treatments. Seed and stalk yield (702 and $1088 \mathrm{~kg} / \mathrm{ha}$, respectively) was recorded significantly higher in $\mathrm{T}_{1}-$ sole sesamum and $T_{3}$ - sole sesamum (Paired rows at 30-30-75 $\mathrm{cm}$ ), respectively over intercropping treatments. Among the intercropping treatments, sesamum + green gram (Paired 3:2) $\left(\mathrm{T}_{7}\right)$ recorded maximum seed as well as stalk yield followed by sesamum + green gram (Paired 2:1) $\left(\mathrm{T}_{6}\right)$.

\section{Introduction}

Sesamum (Sesamum indicum L.) is one of the most ancient oilseed crops grown for over 5000 years. Sesamum is also popularly known as sesame, til, simsim, benised, gingelly, gergelim, etc. It is generally cultivated throughout the year, i.e., during kharif, semi rabi and summer as a sole as well as mixed/intercrop. It is one of the most preferred oilseed crops under rainfed condition even with low yield level because of its higher price and good quality oil. It is very sensitive to biotic and abiotic stresses as a result uncertainty prevails with sesamum cultivation.

Sesamum is a rich source of oil (46-52\%) and protein (18-20\%). Sesamum seeds are also rich in calcium, phosphorus, potassium, vitamin E. Its high quality and staple oil have a high index of sesamin, sesamol and sesamolin antioxidants as well as monounsaturated and polyunsaturated fatty 
acids (Rangkadilok et al., 2010). The presence of antioxidants makes the sesamum oil highly preservable as a result of which it does not get rancid (Ahuja et al., 1971).

Any scheme or plan to increase food and oil production cannot be a total success unless and until an appropriate production-oriented cropping system and production technology are developed and implemented properly. The practice of multi-cropping in the form of intercropping has been a unique asset of tropical and subtropical areas and is becoming popular day by day among small farmers. The advantages of intercropping may be especially important because they are achieved not by means of costly inputs, but by the simple expedient of growing crop together (Willey, 1979).

Early maturing, relative thermo and photoinsensitivity and better canopy structure in pulses make them the ideal candidates for inclusion in multiple cropping systems. Sesamum and pulses viz., green gram, black gram and cowpea which are drought resistant and grown under low level management conditions may be ideal combination for sustainable cropping systems.

\section{Materials and Methods}

A field experiment was carried out during summer season of 2015-16 at College Farm, Navsari Agricultural University, Navsari (Gujarat). The climate of this zone is typically tropical, characterized by humid and warm monsoon with heavy rains, cold winter and fairly hot summer.

The average annual rainfall of the tract is about $1500 \mathrm{~mm}$. The summer season commences by the middle of February and the temperature reaches to its maximum in April or May. Thus, April and May are the hottest months of the season/year.
It is evident from the data presented in Figure 1 that the maximum and the minimum temperature ranged from 29.5 to $38.0^{\circ} \mathrm{C}$ and 12.9 to $28.4^{\circ} \mathrm{C}$, respectively. The maximum and the minimum relative humidity ranged from 69.6 to 91.4 and 21.1 to 76.9 per cent, respectively. The bright sunshine hours varied from 7.5 to 10.5 to hours. The overall meteorological data revealed that the weather and climate conditions were normal and favorable for the growth and development of sesamum and pulse crops.

The experimental field was clayey in texture and showed low, medium and high rating for available nitrogen (197.26 kg/ha), phosphorus (30.93 kg/ha) and potassium (369.80 kg/ha), respectively. The soil was slightly alkaline $(\mathrm{pH}$ 7.6) with normal electric conductivity $(0.32 \mathrm{dS} / \mathrm{m})$.

Total nine treatments viz., $\mathrm{T}_{1}-$ sole sesamum, $\mathrm{T}_{2}-$ sole sesamum (Paired rows at $30-60 \mathrm{~cm}$ ), $\mathrm{T}_{3}$ - sole sesamum (Paired rows at 30-30-75 $\mathrm{cm}), \mathrm{T}_{4}$ - sole green gram, $\mathrm{T}_{5}$ - sole cowpea, $\mathrm{T}_{6}$ - sesamum + green gram (Paired 2:1), $\mathrm{T}_{7}-$ sesamum + green gram (Paired 3:2), $\mathrm{T}_{8}-$ sesamum + cowpea (Paired 2:1) and $\mathrm{T}_{9}-$ sesamum + cowpea (Paired 3:2) were evaluated in randomized block design with four replications.

The recommended dose of NPK was 50-25$00 \mathrm{~kg} / \mathrm{ha}$ for sesamum while, this value for sole intercrop was 20-40-00 kg/ha. As the seeds of sesamum are very small in size, seeds were mixed with powered farm yard manure for the uniform distribution. The plot wise quantity of seed was weighted and sown manually at a depth of $2-3 \mathrm{~cm}$ in the furrow. At the same time, green gram and cowpea seeds were sown in marked rows. Seed were covered properly with soil and irrigation was applied carefully in each plot immediately after sowing. One intercultural operation was carried out by using mechanical weeder at 20 
day after sowing followed by two hand weeding at 25 and 40 days after sowing.

The statistical analysis of data recorded for different characters during the course of investigation was carried out through the procedure appropriate to the Randomized Block Design of the experiment as described by Panse and Sukhatme (1967). The significance of difference was tested by ' $F$ ' test. Five per cent level of significance was used to test the significance of results. The critical differences were calculated when the differences among treatments were found significant in ' $\mathrm{F}$ ' test. In the remaining cases, only standard error of means was worked out. The co-efficient of variance (C.V. \%) was also worked out.

\section{Results and Discussion}

\section{Growth characters}

\section{Plant stand}

The results (Table 1) showed non-significant influence of different treatments on plant stand of sesamum at harvest. This was mainly due to the fact that a uniform sesamum stand in each row was maintained by thinning in all the treatments and may also be due to that the row ratios were arranged in such a way that number of sesamum rows were the same in all the treatments and no competition between inter row and intra row crops. Similar findings were also reported by Bhatti et al., (2005).

\section{Plant height (cm)}

The results (Table 1) showed non-significant effect of various treatments on plant height of sesamum up to 30 DAS, while the differences were significant at 60 DAS and harvest. The results revealed that all the sole sesamum treatments viz., sole sesamum, sole sesamum
(Paired rows at 30-60 $\mathrm{cm}$ ) and sole sesamum (Paired rows at 30-30-75 cm) were statistically at par. Plant height of sesamum was significantly increased due to intercropping treatments.

Intercropping of green gram with sesamum (Paired 3:2) $\left(\mathrm{T}_{7}\right)$ recorded highest plant height, i.e., 68.64 and $102.59 \mathrm{~cm}$ at 60 DAS and harvest, respectively, which was at par with rest of the intercropping treatments viz., $\mathrm{T}_{9}-$ sesamum + cowpea (Paired 3:2), $\mathrm{T}_{6}-$ sesamum + green gram (Paired 2:1) and $\mathrm{T}_{8}-$ sesamum + cowpea (Paired 2:1). This might be due to competition between plants for sunlight absorption as well as legumes improved nitrogen status of the soil which made available to sesamum. Considerably higher plant height of sesamum under different intercropping treatments as compared to sole sesamum was also reported by Samui et al., (1993) and Krishna and Reddy (2005).

\section{Number of branches per plant}

Normal sowing sole sesamum $\left(\mathrm{T}_{1}\right)$ recorded significantly higher number of branches per plant, i.e., 3.00 and 3.90 at 45 DAS and harvest, respectively. Inversely to plant height, number of branches per plant were reduced remarkably under intercropping treatments (Table 1). This might be due to more competition among plants (Sesamum as well as intercrops) for light, space, water and nutrients. These results corroborate the earlier findings of Sarkar et al., (2003) and Kumar and Thakur (2006).

\section{Dry matter accumulation (g/plant)}

The results revealed that all the sole sesamum treatments viz., $\mathrm{T}_{1}$ - sole sesamum, $\mathrm{T}_{2}$ - sole sesamum (Paired rows at $30-60 \mathrm{~cm}$ ) and $\mathrm{T}_{3}-$ sole sesamum (Paired rows at 30-30-75 cm) with dry matter accumulation per plant of 
6.13, 6.05 and $5.94 \mathrm{~g} / \mathrm{plant}$ at 45 DAS and $12.08,11.97$ and $11.89 \mathrm{~g} /$ plant at harvest, respectively, were statistically at par. All the intercropping treatments except $\mathrm{T}_{7}-$ sesamum + green gram (Paired 3:2) recorded significantly lower dry matter accumulation as compared to sole sesamum $\left(\mathrm{T}_{1}, \mathrm{~T}_{2}\right.$ and $\left.\mathrm{T}_{3}\right)$.

\section{Days to 50\% flowering}

The data on days to 50 per cent flowering as influenced by various treatments (Table 1) showed that all the intercropping treatments slightly delayed days to 50 per cent flowering, but the differences were statistically nonsignificant.

\section{Yield attributes}

\section{Number of capsule per plant}

All the sole sesamum treatments viz., $\mathrm{T}_{1}-$ sole sesamum, $\mathrm{T}_{2}$ - sole sesamum (Paired rows at $30-60 \mathrm{~cm}$ ) and $T_{3}$ - sole sesamum (Paired rows at 30-30-75 cm) were statistically at par and recorded more number of capsules per plant $(32.15,31.70$ and 30.95 , respectively) as compared to intercropping treatments. Among the intercropping treatments, $\mathrm{T}_{7}-$ sesamum + green gram (Paired 3:2) recorded higher number of capsule per plant (28.35) and it was at par with all the other intercropping treatments.

\section{Capsule length $(\mathrm{cm})$}

Intercropping of green gram and cowpea with sesamum in different row ratios reduced the capsule length as compared to sole sesamum. Among the intercropping treatments, $\mathrm{T}_{6}-$ sesamum + green gram (Paired 2:1) recorded the maximum capsule length $(2.85 \mathrm{~cm})$.

\section{Number of seeds per capsule}

The results showed that intercropping of green gram and cowpea with sesamum in different row ratios reduced the number of seeds per capsule as compared to sole sesamum. Among the intercropping treatments, $\mathrm{T}_{7}-$ sesamum + green gram (Paired 3:2) recorded the maximum number of seeds per capsule (37.68).

\section{Test weight (g)}

The difference in the test weight of sesamum under sole sesamum treatments $\left(T_{1}, T_{2}\right.$ and $\mathrm{T}_{3}$ ) were statistically at par. Test weight was decreased under intercropping treatments.

Among the intercropping treatments, $\mathrm{T}_{6}-$ sesamum + green gram (Paired 2:1) recorded the maximum test weight $(3.16 \mathrm{~g})$, but the differences were statistically non-significant as compared to rest of the intercropping treatments $\left(\mathrm{T}_{7}, \mathrm{~T}_{8}\right.$ and $\left.\mathrm{T}_{9}\right)$.

Lower values of yield attributes under intercropping treatments might be due to the suppressing effect of fast growing, vigorous growth of broad leaved canopied intercrop.

These findings are in conformity with the results recorded by Sarkar et al., (2003) and Bhatti et al., (2005) who also observed lower number of capsule per plant, number of seeds per capsule and test weight of sesamum under intercropping treatments with different legume/pulse intercrops.

\section{Yield potential}

\section{Seed yield $(\mathrm{kg} / \mathrm{ha})$}

The results (Table 2) revealed that sole sesamum viz., normal sowing, paired rows at $30-60 \mathrm{~cm}$ and paired rows at $30-30-75 \mathrm{~cm}$ with 702, 691 and $682 \mathrm{~kg} / \mathrm{ha}$ seed yield were statistically at par and recorded significantly higher seed yield as compared to all sesamum + green gram and sesamum + cowpea intercropping treatments. 
Table.1 Growth characters of sesamum as influenced by sole and intercropping treatments

\begin{tabular}{|c|c|c|c|c|c|c|c|c|c|}
\hline \multirow{3}{*}{ Treatments } & \multirow{3}{*}{$\begin{array}{l}\text { Final } \\
\text { plant } \\
\text { stand }\end{array}$} & \multicolumn{3}{|c|}{ Plant height (cm) } & \multirow{2}{*}{\multicolumn{2}{|c|}{$\begin{array}{c}\text { Number of branches } \\
\text { per plant }\end{array}$}} & \multirow{2}{*}{\multicolumn{2}{|c|}{$\begin{array}{c}\text { Dry matter } \\
\text { accumulation (g/plant) }\end{array}$}} & \multirow{3}{*}{$\begin{array}{c}\text { Days to } \\
50 \% \\
\text { flowering }\end{array}$} \\
\hline & & \multirow{2}{*}{$\begin{array}{c}30 \\
\text { DAS }\end{array}$} & \multirow{2}{*}{$\begin{array}{c}\text { 60 } \\
\text { DAS }\end{array}$} & \multirow{2}{*}{$\begin{array}{c}\text { At } \\
\text { harvest }\end{array}$} & & & & & \\
\hline & & & & & 45 DAS & At harvest & 45 DAS & At harvest & \\
\hline Sole sesamum & 8.00 & 10.92 & 60.05 & 88.54 & 3.00 & 3.90 & 6.13 & 12.08 & 46.00 \\
\hline Sole sesamum (Paired rows at $30-60 \mathrm{~cm}$ ) & 7.63 & 10.96 & 60.97 & 89.98 & 2.95 & 3.70 & 6.05 & 11.97 & 46.50 \\
\hline $\begin{array}{l}\text { Sole sesamum (Paired rows at } 30-30-75 \\
\mathrm{~cm} \text { ) }\end{array}$ & 7.38 & 10.97 & 61.70 & 90.93 & 2.85 & 3.65 & 5.94 & 11.89 & 46.75 \\
\hline Sole green gram & - & - & - & - & - & - & - & - & - \\
\hline Sole cowpea & - & - & - & - & - & - & - & - & - \\
\hline Sesamum + green gram (Paired 2:1) & 7.13 & 11.28 & 65.81 & 95.50 & 2.25 & 3.20 & 5.06 & 9.82 & 48.25 \\
\hline Sesamum + green gram (Paired 3:2) & 7.25 & 11.37 & 68.64 & 102.59 & 2.65 & 3.55 & 5.45 & 10.53 & 47.00 \\
\hline Sesamum + cowpea (Paired 2:1) & 6.75 & 11.16 & 65.16 & 95.10 & 2.15 & 3.10 & 4.82 & 9.11 & 49.25 \\
\hline Sesamum + cowpea (Paired 3:2) & 7.00 & 11.27 & 67.04 & 97.33 & 2.40 & 3.30 & 5.02 & 9.96 & 48.50 \\
\hline S.Em. \pm & 0.37 & 0.43 & 1.99 & 2.69 & 0.15 & 0.16 & 0.24 & 0.62 & 1.60 \\
\hline C.D. (0.05) & NS & NS & 5.91 & 7.98 & 0.44 & 0.46 & 0.72 & 1.85 & NS \\
\hline
\end{tabular}

Table.2 Yield attributes and yield of sesamum as influenced by sole and intercropping treatments

\begin{tabular}{|c|c|c|c|c|c|c|c|c|}
\hline Treatments & $\begin{array}{c}\text { No. of } \\
\text { capsule } \\
\text { per plant }\end{array}$ & $\begin{array}{c}\text { Capsule } \\
\text { length } \\
(\mathrm{cm}) \\
\end{array}$ & $\begin{array}{c}\text { No. of } \\
\text { seeds per } \\
\text { capsule } \\
\end{array}$ & $\begin{array}{c}\text { Test } \\
\text { weight } \\
\text { (g) }\end{array}$ & $\begin{array}{c}\text { Seed yield } \\
\text { (kg/ha) }\end{array}$ & $\begin{array}{c}\text { Stalk } \\
\text { yield } \\
\text { (kg/ha) }\end{array}$ & $\begin{array}{c}\text { Harvest } \\
\text { index }(\%)\end{array}$ & $\begin{array}{c}\text { Sesamum } \\
\text { equivalent } \\
\text { yield (kg/ha) }\end{array}$ \\
\hline Sole sesamum & 32.15 & 3.25 & 41.70 & 3.25 & 702 & 1057 & 39.87 & 702 \\
\hline Sole sesamum (Paired rows at $30-60 \mathrm{~cm}$ ) & 31.70 & 3.18 & 39.23 & 3.28 & 691 & 1072 & 39.22 & 691 \\
\hline Sole sesamum (Paired rows at $30-30-75 \mathrm{~cm}$ ) & 30.95 & 3.10 & 39.08 & 3.23 & 682 & 1088 & 38.61 & 682 \\
\hline Sole green gram & - & - & - & - & - & - & - & 1012 \\
\hline Sole cowpea & - & - & - & - & - & - & - & 695 \\
\hline Sesamum + green gram (Paired 2:1) & 27.70 & 2.85 & 36.35 & 3.16 & 518 & 862 & 37.71 & 838 \\
\hline Sesamum + green gram (Paired 3:2) & 28.35 & 2.66 & 37.68 & 3.11 & 530 & 871 & 37.89 & 944 \\
\hline Sesamum + cowpea (Paired 2:1) & 26.60 & 2.64 & 35.23 & 3.08 & 472 & 824 & 36.75 & 695 \\
\hline Sesamum + cowpea (Paired 3:2) & 27.90 & 2.45 & 37.60 & 3.03 & 505 & 855 & 37.33 & 803 \\
\hline S.Em. \pm & 1.15 & 0.16 & 0.99 & 0.05 & 29 & 60 & 1.89 & 45 \\
\hline C.D. $(0.05)$ & 3.41 & 0.46 & 2.94 & 0.15 & 87 & 180 & $\mathrm{NS}$ & 133 \\
\hline
\end{tabular}


Fig.1 Mean weekly meteorological data during crop season of the year 2016

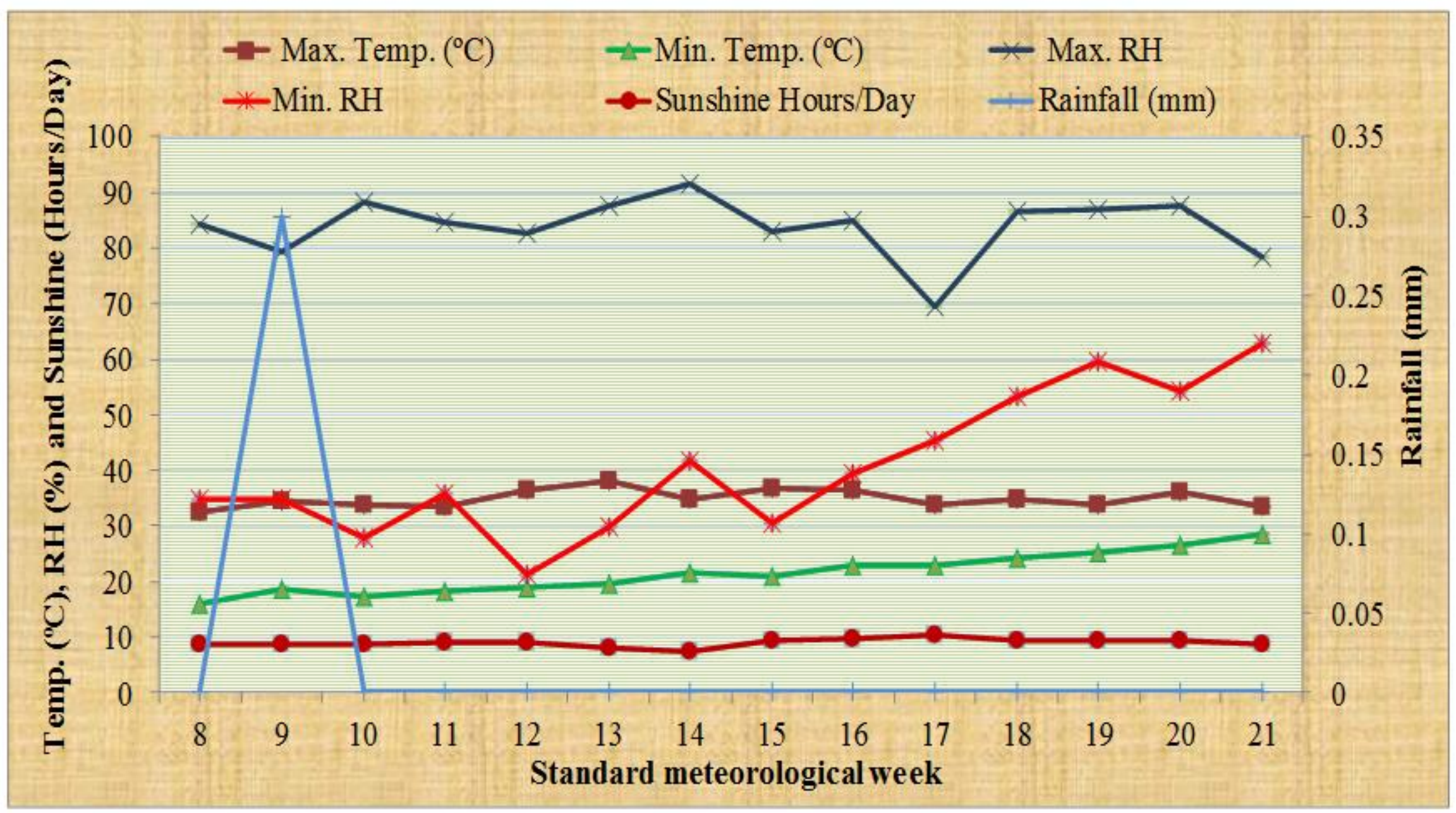


Comparison of intercropping treatments showed that sesamum + green gram (Paired 3:2) recorded the maximum seed yield of sesamum followed by sesamum + green gram (Paired 2:1).

The reduction in seed yield of sesamum under intercropping treatments could be assigned to lower values of almost all yield attributes viz., number of capsule per plant, capsule length, number of seeds per capsule and test weight under intercropping treatments resulting from poor plant growth due to competition effect between sesamum and intercrops for resources like sun light, space, moisture and plant nutrients. Reduction in seed yield of sesamum owing to legume intercropping was also reported by Sridhar et al., (2002), Bhatt et al., (2010), Yadav et al., (2013) and Mandal and Pramanick (2014). The maximum reduction in seed yield of sesamum due to cowpea intercropping can be ascribed to its relatively luxuriant vegetative growth of cowpea as compared to green gram which supress the growth of sesamum. Similar results are also in agreement with the findings of Bhatti et al., (2005).

\section{Stalk yield (kg/ha)}

Sole sesamum sown at $30-30-75 \mathrm{~cm}$ spacing $\left(\mathrm{T}_{3}\right)$ recorded the highest stalk yield of sesamum $(1088 \mathrm{~kg} / \mathrm{ha})$ closely followed by sole sesamum sown at $30-60 \mathrm{~cm}$ spacing $\left(\mathrm{T}_{2}\right)$ (1072 kg/ha) and sole sesamum normal sowing $\left(\mathrm{T}_{1}\right)(1057 \mathrm{~kg} / \mathrm{ha})$. Sesamum stalk yield was decreased significantly due to intercropping of green gram and cowpea in different row ratios. All the intercropping treatments were statistically at par with respect to stalk yield of sesamum.

\section{Harvest Index (\%)}

The data pertaining to the harvest index of sesamum as affected by different treatments
(Table 2) showed non-significant influence of different treatments on harvest index of sesamum. Harvest index was reduced numerically under intercropping treatments.

\section{Sesamum equivalent yield (kg/ha)}

The results (Table 2) revealed that sesamum equivalent yield was influenced significantly due to various intercropping treatments. Introducing green gram or cowpea intercrop with sesamum in different row ratios exhibited rise in sesamum equivalent yield to varying extent except sesamum + cowpea in 2:1 ratio $\left(\mathrm{T}_{8}\right)$. Out of intercropping treatments, $\mathrm{T}_{7}-$ sesamum + green gram (Paired 3:2) recorded the highest $(944 \mathrm{~kg} / \mathrm{ha})$ sesamum equivalent yield which was statistically at par with $\mathrm{T}_{6}-$ sesamum + green gram (Paired 2:1). Conversion of green gram and cowpea yield under sole stand $\left(\mathrm{T}_{4}\right.$ and $\mathrm{T}_{5}$, respectively) into sesamum equivalent yield revealed that former was significantly higher over sole sesamum yield recorded in $\mathrm{T}_{1}, \mathrm{~T}_{2}$ and $\mathrm{T}_{3}$. Maximum sesamum equivalent yield was observed in sole green gram $\left(\mathrm{T}_{4}\right)$ which might be due to higher price of green gram seed. Higher sesamum equivalent yield in these intercropping treatments indicated yield advantages over sole sesamum. Higher sesamum equivalent yield due to introducing of legumes in sesamum were also reported by Mandal and Pramanick (2014) in sesame + green gram $(2: 2)$.

\section{References}

Ahuja, K.I., Sekhon, J.S. and Gupta, T.R. 1971. Effect of some cultural treatments on the yield and chemical composition of sesame (Sesamum indicum L.). Indian J. Agron., 16(4): 445-448.

Bhatt, B.K., Dixit, S.K. and Darji, V.B. 2010. Monetary evaluation of sesame based intercropping systems. Indian J. Agri. Res., 44(2): 146-149. 
Bhatti, I.H., Ahmad, R. and Nazir, M.S. 2005. Agronomic traits of sesame as affected by grain legumes intercropping and planting patterns. Pak. J. Agri. Sci., 42: $1-2$.

Krishna, M.H. and Reddy, A.P.K. 2005. Studies on intercropping green gram in summer sesame, Sesamum indicum L. J. Oilseeds Res., 22(1): 201-203.

Kumar, A. and Thakur, K.S. 2006. Production potential and economic feasibility of sesame (Sesamum indicum L.) based intercropping with legumes under rainfed conditions. Indian J. Agri. Sci., 76(3): 183-184.

Mandal, M.K. and Pramanick, M. 2014. Competitive behaviour of component crops in sesame greengram intercropping systems under different nutrient management. The Bioscan, 9(3): 1015-1018.

Panse, V.G. and Sukhatme, P.V. 1967. "Statistical Methods for Agricultural Workers". ICAR, New Delhi.

Rangkadilok, N., Pholphana, N., Mahidol, C., Wongyai, W., Saengsooksree, K., Nookabkaew, S. and Satayavivad, J. 2010. Variation of sesamin, sesamolin and tocopherols in sesame (Sesamum indicum L.) seeds and oil products in Thailand. Food Chem., 122(3): 724730.
Samui, R.C., Sengupta, S. and Roy, B. 1993. Effect of intercropping on yield and economics of sesame and green gram. $J$. Oilseeds Res., 10(1): 20-24.

Sarkar, R.K., Malik, G.C. and Goswami, S. 2003. Productivity potential and economic feasibility of sesame (Sesamum indicum L.)-based intercropping system with different planting patterns on rainfed upland. Indian J. Agron., 48(3): 164-167.

Sridhar, P., Manickam, G., Chinnasamy, K. and Rajamanickam, B. 2002. Studies on the productivity potential and economics of different sesame (Sesamum indicum L.) based intercropping systems. Crop Res., 23(3): 437-439.

Willey, R.W. 1979. Intercropping - its importance and research needs. Part-I. Competition and yield advantages. Field Crop Abstract, 32(1): 1-10.

Yadav, P.N., Uttam, S.K., Singh, R.P., Katiyar, S.C., Tripathi, A.K. and Kanaujia, D.K. 2013. Productivity, economic viability, water use efficiency, reciprocity functions and energy efficiency of sesame (Sesamum indicum L.)- based intercropping in rainfed ecosystem. Curr. Adv. Agri. Sci., 5(1): 59-63.

\section{How to cite this article:}

Dinesh Kumar, R.B. Ardeshna, B.R. Verma and Patel, A.K. 2017. Growth and Yield Performance of Summer Sesamum Based Intercropping Systems. Int.J.Curr.Microbiol.App.Sci. 6(6): 3341-3348. doi: https://doi.org/10.20546/ijcmas.2017.606.292 